\title{
Hearing aids re-habilitation in aged people
}

\author{
E Marciano \\ From de Senectute: Age and Health Forum \\ Catanzaro, Italy. 5-7 December 2009
}

Presbyacusis is defined as the cumulative effects of aging on hearing ability. Each of them commonly feature different impairments, e.g on: sound hearing (mostly for high frequencies), speech understanding (mostly in noise), delayed speech processing by NCS and sound source localization. Its fuzzy and unclear simptomatology frequently leads to a delayed detection. In addition, the affected subjects rarely contact a specialist in order to sharply deal with such occurrences. Furthermore, whenever the presbyacusis is detected, only a small amount of patients will use hearing aids. To date, in US only the $20 \%$ of people supposed to need a hearing support, wear hearing aids and the $25-40 \%$ of those patients either leave or use them unevenly.

Aims of this report are:

- to examine the reasons leading people affected by presbyacusis to rarely wear hearing aids

- to verify the possible technical hitches on fitting hearing-aids to aged patients (prosthetic grading), in order to provide them with correct rehabilitation pathways to an adequate sound and speech perception.

The last part of this work concerns the rehabilitation issues for subjects affected by a multi-sensorineural impairment (e.g deaf-blindness).

Submit your next manuscript to BioMed Central and take full advantage of:

- Convenient online submission

- Thorough peer review

- No space constraints or color figure charges

- Immediate publication on acceptance

- Inclusion in PubMed, CAS, Scopus and Google Scholar

- Research which is freely available for redistribution

Submit your manuscript at www.biomedcentral.com/submit
C Biomed Central 